\title{
The Annals of
}

lowa Volume 79 Number 3 Summer 2020

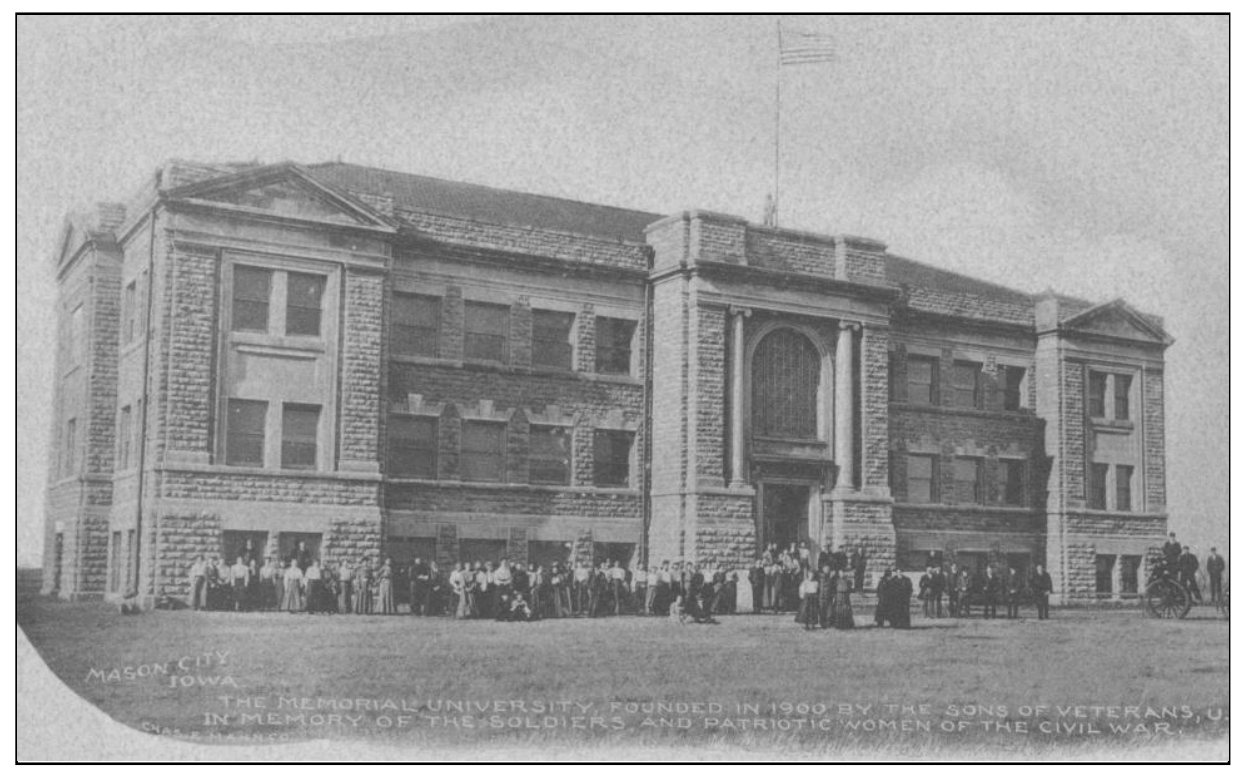

A QUARTERLY JOURNAL OF HISTORY 


\section{In This Issue}

JONATHAN D. NEU examines the institutional history of Memorial University-a college, normal school, and preparatory academy in Mason City, Iowa, founded in the early 1900s. He argues that the short-lived school linked a Grand Army of the Republic-endorsed memory of the Civil War with Progressive Era educational reform.

EMILY PRIFOGLE demonstrates how prosecutorial discretion functioned in the small town of Storm Lake, Iowa, in the 1920s. Through the memoirs of county attorney Charles Pendleton, she shows how rural social networks and local norms concerning race, religion, gender, sexuality, and temperance informed prosecutorial acts of discretion in the early twentieth century.

\section{Front Cover}

Image of the first building completed at Memorial University in Mason City, Iowa, which was meant to be a harbinger of the grand university that the Grand Army of the Republic planned to build in the community. For more on the rise, decline, and influence of Memorial University, see Jonathan D. Neu's article in this issue. Photo courtesy of Jonathan D. Neu.

\section{Editorial Consultants}

Rebecca Conard, Middle Tennessee State University

Kathleen Neils Conzen, University of Chicago

William Cronon, University of WisconsinMadison

Robert R. Dykstra, State University of New York at Albany
R. David Edmunds, University of Texas at Dallas

H. Roger Grant, Clemson University

William C. Pratt, University of Nebraska at Omaha

Pamela Riney-Kehrberg, Iowa State University

Malcolm J. Rohrbough, University of Iowa 


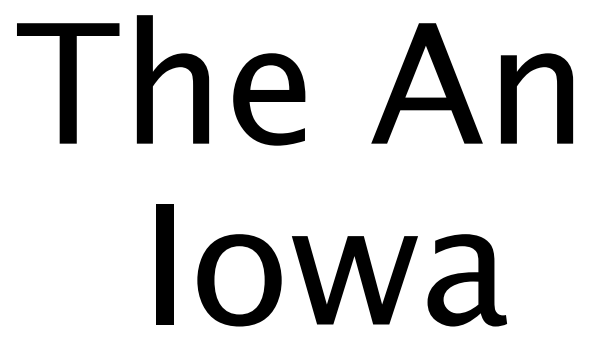

Third Series, Vol. 79, No. 3

Summer 2020

Andrew Klumpp, editor

\section{Contents}

211 "Produce Patriots As Well As Scholars": GAR Educational Reform and the Establishment of Mason City's Memorial University Jonathan D. Neu

247 Winks, Whispers, and Prosecutorial Discretion in Rural Iowa, 1925-1928

Emily Prifogle

$285 \quad$ Book Reviews and Notices 


\section{Book Reviews and Notices}

285 JON K. LAUCK, ED., The Interior Borderlands: Regional Identity in the Midwest and Great Plains, by Amanda Rees

286 PEKKA HÄMÄLÄINEN, Lakota America: A New History of Indigenous Power, by Stephen Hausmann

288 KRISTOPHER MAULDEN, The Federalist Frontier: Settler Politics in the Old Northwest, 1783-1840, by Nicole Etcheson

290 Michael A. LofARO, ED., Boone, Black Hawk, and Crockett in 1833: Unsettling the Mythic West, by Patrick J. Jung

292 Thomas G. AleXANDER, Brigham Young and the Expansion of the Mormon Faith, by Richard D. Ouellette

294 CANDy Moulton, The Mormon Handcart Migration: "Tounge nor pen can never tell the sorrow," by Chad M. Orton

296 ZaCHARY StUART GARRISON, German Americans on the Middle Border: From Antislavery to Reconciliation, by Petra DeWitt

298 Evan KutZler, Living by Inches: The Smells, Sounds, Tastes, and Feeling of Captivity in Civil War Prisons, by Patrick G. Bass

300 Jo AnN Daly CARR, ED., Such Anxious Hours: Wisconsin Women's Voices from the Civil War, by Ginette Aley

301 David Connon, Iowa Confederates in the Civil War, by Tim Roberts

303 R. Eli PAUL, ED., The Frontier Army: Episodes from Dakota and The West, by Paul N. Beck

305 Thomas J. Brown, Civil War Monuments and the Militarization of America, by Edith M. Hunter

306 John RADZILOWSKI AND ANN Hetzel GunKel, Poles in Illinois, by William J. Galush

308 Ben Nicholson And Michelangelo Sabatino, EDS., Avant-Garde in the Cornfields: Architecture, Landscape, and Preservation in New Harmony, by Thomas A. Guiler 